\title{
Urban Forests of Samara-Togliatti Agglomeration: Land Use and Protection Issues
}

\author{
A.A. Kondolskaya ${ }^{1, *}$ and D.I. Vasilieva ${ }^{1}$ \\ *Corresponding author: kondolskaya@icloud.com \\ ${ }^{1}$ Samara State University of Economics, Samara, Russia
}

\begin{abstract}
The territories of urban agglomerations are most susceptible to anthropogenic impact. At the same time, the area of urban forests of the Samara-Tolyatti agglomeration (further referred to as STA) has significantly decreased in recent years. A pressing issue is the preservation of the remaining forests in the cities of the agglomeration. The purpose of the study is to compile a balance of urban STA forests, as well as an analysis of the legal regime for their use and identification of violations in this area. The main research method is the analysis and synthesis of available materials. The result of the study is to identify problems in the use and protection of urban land.
\end{abstract}

Keywords: Samara-Togliatti agglomeration, Urban Forests, ecological condition, Samara region.

\section{Introduction}

Urban forests occupy a small area of the land fund of the Russian Federation while performing the most important environmental functions. Most of the population lives in urban areas. Therefore, the problems of reducing the level of air pollution, noise pollution and, in general, improving the quality of the urban environment are of paramount importance. At the same time, the lands of urban forests do not have sufficient restrictions established in the legislation at the federal level on their economic use, which leads to a constant change of zoning for land plots of urban forests and further real estate development.

\section{Problem Statement}

The main difference of urban forests from other groups of the forest fund is their location within the boundaries of settlements and, therefore, belonging to the land category of settlements [1]. In urban areas, anthropogenic impact has a different form: from walking paths for the urban dwellers, sports, picnics, picking mushrooms, berries and medicinal plants, hiking, organizing seasonal recreation in pioneer camps, recreation centers and boarding houses to dumps of industrial and domestic garbage. The proximity of recreational areas to residential areas causes a difficult ecological situation in urban forests. The problem of using and protecting the lands of urban forests is considered on the example of the urban forests of the Samara-Tolyatti agglomeration. As part of the study, it is necessary to identify the main causes of the deterioration of urban forests and the reduction of their area.

\section{Research Questions}

Large-scale transformations occurring in both the economic and social spheres of the Russian Federation predetermine the need for studying the main directions of the territorial development of the country's regions [2]. Nowadays, the term "agglomeration" is increasingly common in the scientific literature. This concept is defined as the territory in which settlements are located, connected by strong industrial, cultural, social, labor and recreational connections.

Samara-Tolyatti agglomeration (STA) is the largest polycentric agglomeration - conurbation in the Russian Federation. From the point of view of historical development, it can be said that the STA borders become established in the 1930s as a result of a massive migration exodus of the rural population, connected with a change in economic development priorities towards industrialization, to the cities. At that time, the largest cities in the region, Samara and Syzran, increased their numbers almost tenfold. Currently, STA includes 8 urban districts and 9 municipal districts [3].

In recent years, the STA had been an object of research within the framework of the R\&D of the Institute of the State Unitary Enterprise of the Samara Region "TerrNIIigrazhdanproekt" "Monitoring and analysis of the development processes of the territory of the Samara Region", as well as an object of study in scientific works of K.A. Titov, G.R. Khasayev [4], S.I. Komarov, D.V. Antropov [2], etc. In these researches, the considered agglomeration was studied in the context of the 
characteristics of settlement, the development of the logistics system, as well as the formation of economic relations within STA. According to the authors, a comprehensive consideration of the prospects for the development of agglomeration cannot exclude the study and analysis of environmental problems arising in the process of agglomerating territories.

\section{Purpose of the Study}

Solving environmental problems in the process of designing and managing conurbations is one of the major problems in its development. Regardless of the prerequisites for the development of territories and its historical features, the process of agglomeration is currently one of the mechanisms for the territorial development of the country, creating comfortable conditions for the life of the population [5]. The purpose of the study is to compile a balance of urban STA forests, as well as an analysis of the legal regime for their use and to identify violations in this area.

\section{Research Methods}

The main research method is the analysis and synthesis of available materials. We reviewed the websites of key organizations, hand-searched several journals, and examined relevant texts from the reference lists of the documents we had already obtained.

\section{Findings}

The agglomeration is characterized by a high population density, a concentration of production facilities, and a developed engineering and transport infrastructure. In these territories, the problem of preserving the ecological balance is particularly acute and, therefore, constant monitoring of water, air, biological, soil and land resources is important. It is also important to pay attention to the study of the ecological status of forest areas of agglomeration and to the need of identifying of land use and protection problems.

The legal regime established in the territory of urban forests determines their further fate and, above all, the possibility of maintaining a favorable environmental situation. The introduced restrictions reduce the anthropogenic load as a whole and, most significantly, narrow the range of possible uses of forest space [4].

Table 1. STA forests features

\begin{tabular}{|c|c|c|c|c|c|c|}
\hline \multirow[t]{2}{*}{$\begin{array}{l}\text { № } \\
\Pi / \Pi\end{array}$} & \multirow[t]{2}{*}{$\begin{array}{l}\text { Title of forestry } \\
\text { (forest park) }\end{array}$} & \multirow[t]{2}{*}{$\begin{array}{l}\text { Overall } \\
\text { square, } \\
\text { hectare }\end{array}$} & \multirow[t]{2}{*}{$\begin{array}{c}\text { Forests' square, } \\
\text { hectare }\end{array}$} & $\begin{array}{c}\text { Forest area } \\
\text { distribution by } \\
\text { purpose of forests, ha }\end{array}$ & $\begin{array}{c}\text { Total stock } \\
\text { of wood, } \\
\text { thousand } \\
\text { cubic meters } \\
\text { m }\end{array}$ & $\begin{array}{c}\text { Total year } \\
\text { increase in } \\
\text { stock } \\
\text { wood, } \\
\text { thousand } \\
\text { cubic meters } \\
\text { m } \\
\end{array}$ \\
\hline & & & & protective forests & & \\
\hline 1 & 2 & 3 & 4 & 5 & 6 & 7 \\
\hline \multicolumn{7}{|c|}{ 1. Forest-steppe region of the European part of the Russian Federation } \\
\hline \multicolumn{7}{|c|}{ 1.1. Forests located on forest land } \\
\hline 1. & Bezenchuckskoye & 27763,2 & 24201,2 & 24201,2 & 3331,5 & 83,6 \\
\hline 2. & Volzhskoye & 34147,5 & 28282,5 & 28282,5 & 4014,2 & 92,5 \\
\hline 3. & Kinelskoye (part) & 1319 & 1108,2 & 1108,2 & 135,2 & 3,6 \\
\hline 4. & Krasnoyarskoye & 35637,1 & 31652,1 & 31652,1 & 3940,3 & 96,8 \\
\hline 5. & Novo-Buyanskoye & 44781 & 40249 & 40249 & 6093,8 & 130,2 \\
\hline 6. & Racheiskoye & 44280,2 & 42400,2 & 42400,2 & 6122,7 & 147,7 \\
\hline 7. & Stavropolskoye & 14822,3 & 14028,3 & 14028,3 & 2395,3 & 48 \\
\hline 8. & Shigonskoye & 48455 & 44357 & 44357 & 6173,6 & 132,2 \\
\hline \multicolumn{7}{|c|}{ 1.2. Urban forests } \\
\hline 1. & Tolyattinskoye & 8020 & 7559,9 & 7559,9 & 1526,8 & 27,6 \\
\hline 2. & Samarskoye & 8506 & 6324,1 & 6324,1 & 847,4 & 18,8 \\
\hline \multicolumn{7}{|c|}{ 1.3. Natural areas under special protection } \\
\hline 1. & Zhiguli Reserved area & 23157 & 22033 & 22033 & 4548,8 & 68,6 \\
\hline \multirow[t]{2}{*}{2.} & National Park "Samara Luka" & 66486 & 62282 & 62282 & 11799,7 & 214,1 \\
\hline & Total for forest-steppe & 357374,3 & 324477,4 & 324477,4 & 50929,7 & 1063,6 \\
\hline
\end{tabular}




\begin{tabular}{|c|c|c|c|c|c|c|}
\hline \multicolumn{2}{|c|}{ forest area } & & & & & \\
\hline \multicolumn{7}{|c|}{ 2. Steppe region of the European part of the Russian Federation } \\
\hline \multicolumn{7}{|c|}{ Forests located on the lands of the forest fund } \\
\hline 1. & Kinelskoye (part) & 36518,8 & 30864,2 & 30864,2 & 3815,9 & 103,3 \\
\hline & Total for steppe forest area & 36518,8 & 30864,2 & 30864,2 & 3815,9 & 103,3 \\
\hline \multicolumn{2}{|c|}{ Total for STA } & 393893,1 & 355341,6 & 355341,6 & 54745,6 & 1166,9 \\
\hline \multicolumn{2}{|c|}{$\begin{array}{l}\text { Forests located on the lands of the forest } \\
\text { fund }\end{array}$} & 287724,1 & 257142,6 & 257142,6 & 36022,9 & 83768 \\
\hline \multicolumn{2}{|c|}{ Urban forests } & 16526 & 13884 & 13884 & 2374,2 & 46,4 \\
\hline \multicolumn{2}{|c|}{ Natural areas under special protection } & 89643 & 84315 & 84315 & 16348,5 & 282,7 \\
\hline
\end{tabular}

Source: compiled by the authors based on the data publicly available materials [9].

On the territory of the Samara-Tolyatti agglomeration there are more than 393 thousand hectares of forest (Table 1) [6]. The special situation is in the urban forests of STA. Currently Samara city zones of natural landscapes (P-3), on which urban forests are located, are transferred to residential, public and business, garden-dacha areas and collective gardens. The total area of the P-3 zone has significantly decreased in recent years.

For the urban forests of the Samara-Tolyatti agglomeration for a long time, the actual problem was the presence of territories of unrestricted property, for which it was not established who exactly - the federal bodies, the bodies of the subjects of the Russian Federation or the municipality should control the use and protection of public facilities.

Samara urban forests (Fig. 1) have been the subject of disputes on this issue since 2009, when, by a court decision, they lost the status of federal objects. However, the actual transfer of authority over the next nine years did not occur due to bureaucratic delays [7].

At the same time, despite the fact that the Ministry of Forestry, Environmental Protection and Environment Management of the Samara Region doesnot dispose of land plots of urban forests of the city of Samara, for them the established category of land is forest land. A different situation exists in Tolyatti city, where the only forest belongs to the category of land settlements [6]. In accordance with Art. 23 of Forest Code of RF [8] urban forests can fall into this category. There are no legal contradictions here, but this fact testifies to differences in the legal regime of forest use in different cities of the agglomeration.

The situations are united by the implementing of the so-called "On Green Shield" law, signed by the President of the Russian Federation and entered into force in 2017, on the basis of which the "Green Shield" area cannot be changed without public discussion. The law implies fines for violating the rules of cutting trees in "green shield" [9].

A separate problem of "urban forests" is the presence of inconsistencies of town planning regulations with the actual use of land. The rules of land use and development (PZZ) - the main urban planning document of the city - establishes a list of zones, in particular, in accordance with the PZZ of Tolyatti, P-4 is a zone of urban forests and forest parks. The document states that the main types of permitted use of land are: urban forests, tree nurseries, forest trails, urban forest parks, nurseries and greenhouses of landscape gardening, cycling and walking paths, ski trails, ski-roller tracks, as well as other not related to construction. At the same time, conditionally allowed and auxiliary types of permitted use of land plots are absent. So we can conclude, that the territorial zoning document strictly defines the list of possible options for the use of forest areas.

In fact, the situation is different. For example, a land plot with cadastral number 63: 09: 0201057: 16070, located at: Tolyatti, north of the building having the address st. Lisa Chaikina, d. 21, an area of 6297 square meters. According to the public cadastral map (Fig. 2), it has permitted use - for accommodating hotels. At the same time, in accordance with the Land Use and Development Rules, the P-4 zone is established (Fig. 3). As noted above, the construction of capital facilities in this zone is not permissible. 


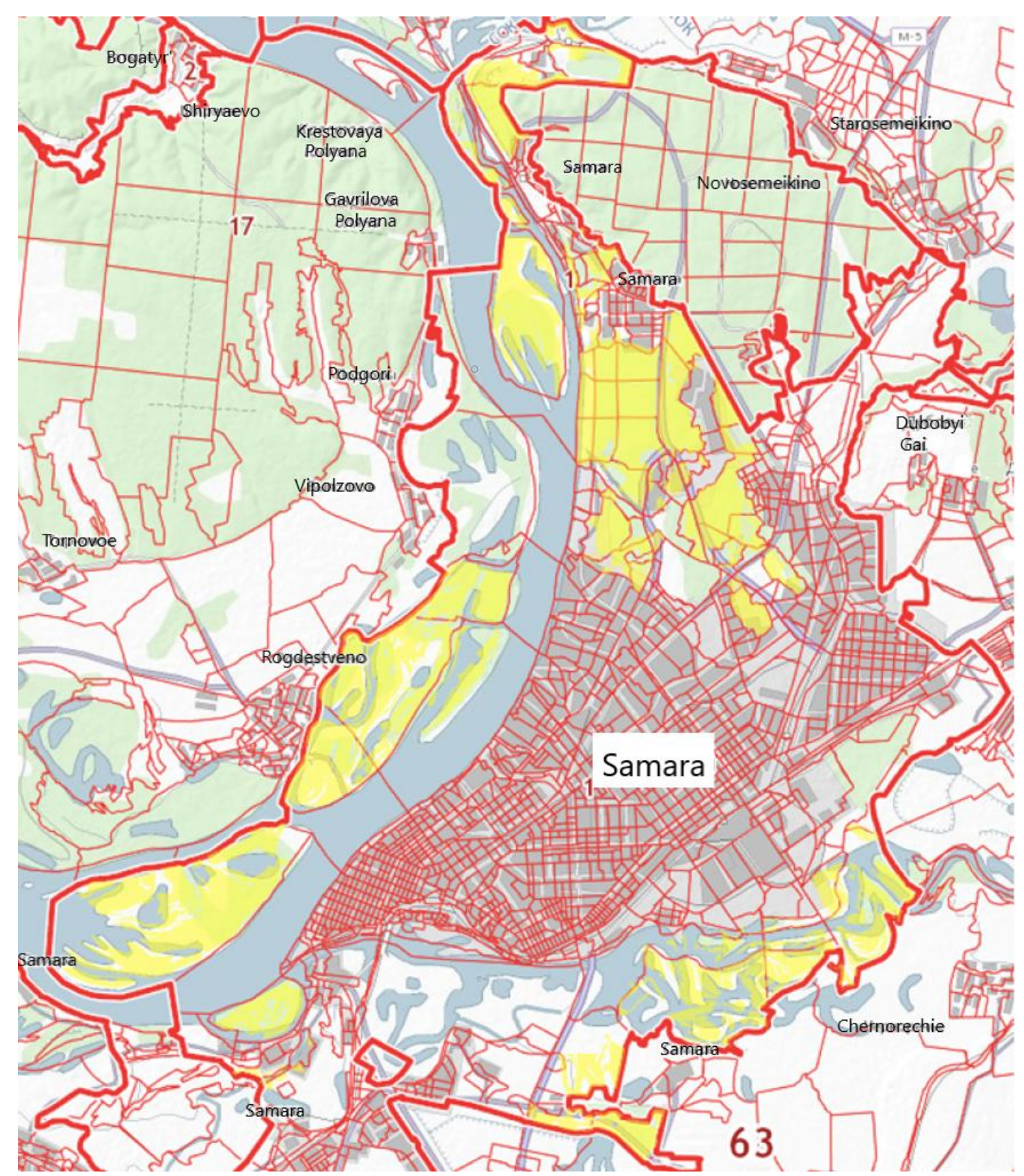

Figure 1. Urban Forests located on the lands of Samara city (Source: according to the public cadastral map) [10]

Such a situation is not uncommon. Therefore, most of the urban forests do not have a protected status and are constantly being cut down, their area is constantly decreasing [11]. Thus, one of the most important areas of management of the Samara-Tolyatti agglomeration and improving the quality of the urban environment is cadastral registration of land plots of preserved urban forests, continuous monitoring of these territories, as well as the implementation of land control to identify inconsistencies of cadastral data with territorial documents planning. First of all, this requires the development of legislation on urban forests at the federal level [12]. 


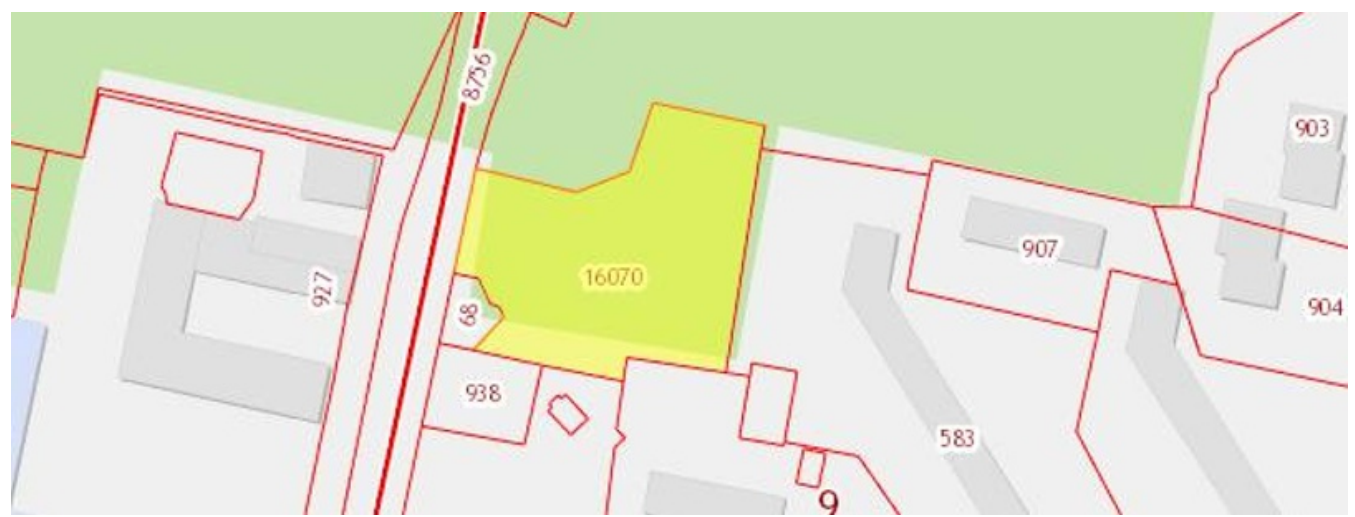

Figure 2. Land plot for accommodation of hotels in the territory of the urban forest. Tolyatti city (Source: according to the public cadastral map) [10]

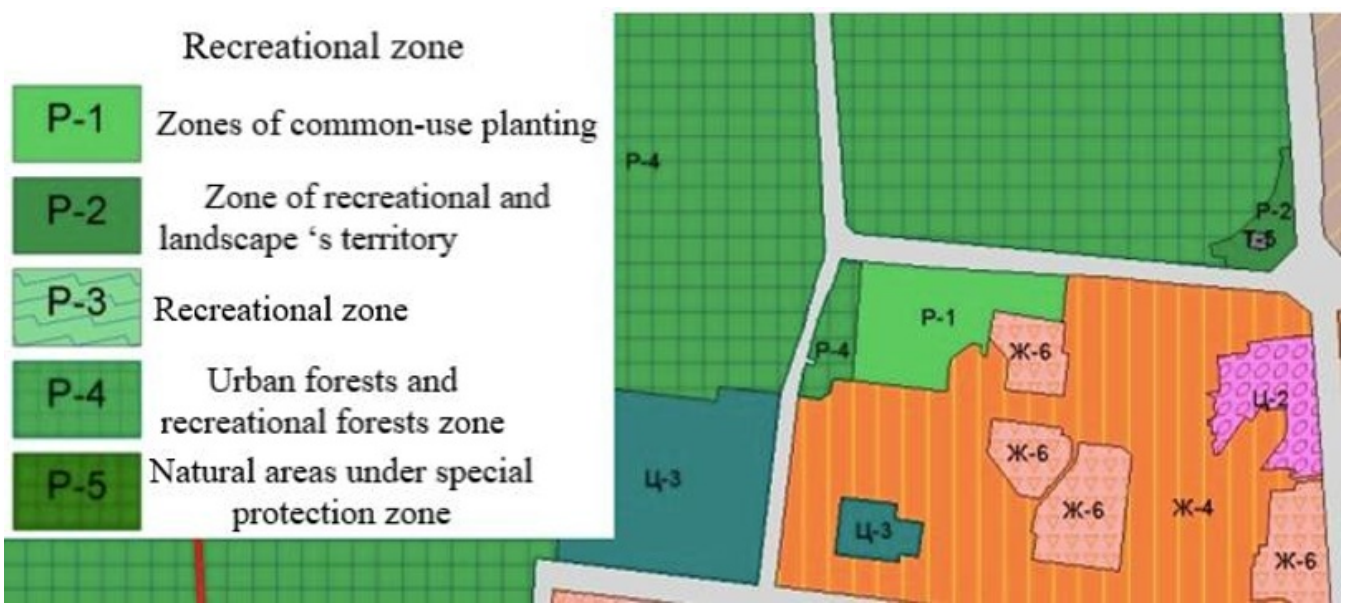

Figure 3. Map tile of town - planning zoning of Tolyatti city

(Source: according to the Rules of land use and development in Togliatti city) [13]

\section{Conclusion}

Any agglomeration is a "living organism" in which continuous changes occur due to various reasons. The study of these processes is the basis for creating a quality managing system for the territory of the agglomeration in order to avoid the chaotic development of its space and the irrational use of land resources. In this case, the most important problem is the improvement of the ecological state of the urban environment, which is impossible to achieve without preserving and increasing the territories of urban forests.

The transformation of agglomerated areas is a long process that can last for decades. Only developed at a high professional level, a consistent plan for spatial resources' managing of agglomerations with an emphasis on preserving natural landscapes with multidimensional, coordinated cooperation of federal, regional and municipal authorities, which differ at various stages of development of the country and the region, should become the basis for such a development.

\section{References}

1. N.V. Kichigin, Urban Forests: the regime of protection and use. Journal of Russian Law, 6, 28-34. URL: https://cyberleninka.ru/article/v/gorodskie-lesa-rezhim-ohrany-i-ispolzovaniya (2011). [in Rus.].

2. S.I. Komarov, D.V. Antropov, Methods of cluster zoning of the territory of the region for land management purposes. UrFU Bulletin. Series: Economics and Management, 1, 66-85. DOI: 10.15826/vestnik.2017.16.1.004 (2017). [in Rus.].

3. D.I. Vasilyeva, A.G. Vlasov, Dynamics of the land fund of the Samara region. In S.I. Pavlov (Ed.), 5th interst. scientific and practical Conf. dedicated to the 110th anniversary of the birth of Dr. Sc., Prof. L.V. Vorzhevoi and the 125th anniversary of the birth of Ph.D., Assoc. G.G. Shtehera (pp.166-169). Samara, Russia: SGSPU (2016). [in Rus.].

4. K.A. Titov, Environmental issues. In G.R. Khasaev (Ed.) Samara-Tolyatti agglomeration: Current state and ways of sustainable development (pp. 115-116). Moscow, Russia: Nauka (1996). [in Rus.]

5. Postanovlenie Pravitel'stva Samarskoy oblasti “O strategii social’no-ekonomicheskogo razvitiya Samarskoy oblasti na 
period do 2030 goda" ot 12.07.2017 N441 Retrieved from: http://docs.cntd.ru/document/450278243. Accessed: 15.12.2018 (2017). [in Rus.].

6. Postanovlenie Gubernatora Samarskoy oblasti "Ob utvergdenii Lesnogo plana Samarskoy oblasti” ot 31.12.2008 N149 Retrieved from: http://docs.cntd.ru/document/945036102. Accessed: 15.12.2018 (2008). [in Rus.].

7. V.V. Voronin, Some results of the implementation of the program to increase the forest growth on the territory of the Samara region under the Kyoto Protocol. Problems of Regional Ecology, 4, 60-66 (2015). [in Rus.].

8. Lesnoi' kodeks Rossiskoi Federacii ot 04.12.2006 N200-FZ Retrieved from: http://docs.cntd.ru/document/902017047. Accessed: 15.12.2018 (2006). [in Rus.].

9. E.P. Pecherskaya, L.V. Dzhabborova, L.V. Averina, I.I. Firulina, M.S. Ivankina, D.A. Akopyan, Cultural heritage sites' protected areas as a tool of urban environment development. EurAsian Journal of BioSciences, 12, 189-194. URL: http://www.ejobios.org/download/cultural-heritage-sites-protected-areas-as-a-tool-of-urban-environmentdevelopment.pdf (2018).

10. Federal Service of State Registration, Cadastre and Cartography: Public cadastral map. Open Data. Retrieved from: https://pkk5.rosreestr.ru/. Accessed: 15.12.2018. [in Rus.].

11. V.V. Voronin, Ecological condition and quality of land in the Samara region. Ecology of Urbanized Territories, 4, 76-86 (2013). [in Rus.].

12. N.G. Narysheva, Development of legislation on urban forests. Environmental Law, 1, 7-13. URL: https://www.booksite.ru/forest/forest/legislation/14.htm (2012). [in Rus.].

13. Administration of Togliatti City, Rules of land use and development in Togliatti city. Retrieved from URL: http://tgl.ru/structure/department/pravila-zemlepolzovaniya-i-zastroyki//. Accessed: 15.12.2018 (2018). [in Rus.]. 